\title{
Establishment and long-term culture of the cell lines derived from gonad tissues of Siberian sturgeon (Acipenser baerii)
}

\author{
Jun Hyung Ryu', Yoon Kwon Nam ${ }^{1,2}$ and Seung Pyo Gong ${ }^{1,2,3^{*}}$
}

\begin{abstract}
To culture germline stem cells in vitro, establishment of the cell lines that can be used as the feeder cells is a prerequisite. In this study, we tried to establish gonad-derived cell lines in Siberian sturgeon (Acipenser baerii). Five 1 -year-old A. baerii were used as a donor of gonad tissues, and gonad-dissociated cells were cultured in vitro. Subsequently, determination of growth conditions, long-term culture, characterization, and cryopreservation of the cell lines were also conducted. Five gonad-derived cell lines were stably established and cultured continuously over at least the 73th passage and 402 culture days under the media containing $20 \%$ fetal bovine serum at $28{ }^{\circ} \mathrm{C}$. All cell lines consisted of two main cell types based on morphology even if the ratio of the two cell types was different depending on cell lines. Despite long-term culture, all cell lines maintained diploid DNA contents and expression of several genes that are known to express in the A. baerii gonad. After freezing and thawing of the cell lines, post-thaw cell viabilities between 57.6 and $92.9 \%$ depending on cell lines were indentified, suggesting that stable cryopreservation is possible. The results and the cell lines established in this study will contribute to the development of an in vitro system for A. baerii germline stem cell culture.
\end{abstract}

Keywords: Sturgeon, Acipenser baerii, Feeder cells, Long-term culture, Germline stem cells

\section{Background}

Germline stem cells are a very important cell type taking charge of gamete production (Brinster, 2007; Spradling et al., 2011; Lehmann, 2012). Due to their high application possibilities to animal transgenic research as a mediator conveying new traits to the next generation, lots of trials for in vitro culture and manipulation of them have been conducted in many mammalian (Guan et al., 2006; Aponte et al., 2008; Lee et al., 2013; Tiptanavattana et al., 2013; Lee et al., 2014) and some avian species (Park et al., 2008; Song et al., 2014). In fish, similar studies have been performed in small fish models (Sakai, 2002; Hong et al., 2004; Fan et al., 2008; Kawasaki et al., 2012; Wong and Collodi, 2013; Wong et al., 2013; Li et al., 2014), but the related ones dealing with large farmed fish have been rarely conducted (Shikina et al., 2008; Shikina and

\footnotetext{
* Correspondence: gongsp@pknu.ac.kr

'Department of Marine Biomaterials and Aquaculture, Pukyong National University, Busan 608-737, South Korea

${ }^{2}$ Department of Fisheries Biology, Pukyong National University, Busan 608-737, South Korea

Full list of author information is available at the end of the article
}

Yoshizaki, 2010; Lacerda et al., 2013). Therefore, establishment of an in vitro culture system for germline stem cells derived from the economically valuable fish is one of the upcoming challenges in the field of fish transgenic research. As one of the important aquaculture fish, the Siberian sturgeon (Acipenser baerii) provides valuable food resources including a luxury food and caviar and has a merit in culture due to its ability to tolerate the changes of environmental factors such as temperature and low $\mathrm{O}_{2}$ concentration (Gisbert and Ruban, 2003). Thus, to fulfill the improvement of the breed of this species, applying transgenic technology is a worthwhile work in regard to commercial aspect. Moreover, establishment of germline stem cells can contribute to species preservation of this endangered fish species (Ruban and Zhu, 2010; Hong et al., 2011; Lacerda et al., 2014).

To establish germline stem cell culture system in $A$. baerii, developing appropriate feeder cell lines that can support germline stem cells in vitro is a top priority. In general, cell lines derived from gonads are known to possess a capacity to support survival, maintenance, 
growth, and differentiation of germline stem cells during in vitro culture (Hofmann et al., 2003; Nagano et al., 2003; Hong et al., 2004). It has been reported that mouse spermatogonial stem cells formed colonies and maintained its characteristics for 5 months on testis-derived feeder cells during in vitro culture (Kanatsu-Shinohara et al., 2012). In fish, trout spermatocytes showed longer survival on Sertoli cells from testis than those without somatic cells in culture (Loir, 1989). Moreover, zebrafish ovarian-somatic feeder cells supported cell growth, survival, and germline competency of female germline stem cells in culture (Wong et al., 2013).

Therefore, in this study, we tried to establish $A$. baerii gonad-derived cell lines as a first step toward culturing A. baerii germline stem cells. Subsequently, we evaluated optimal growth conditions of the established cell lines and characterized them within the framework of the morphology, DNA contents, and expression of genes that are known to express in $A$. baerii gonad. In addition, considering the legal and ethical limitation about killing this endangered species repeatedly to secure a large amount of feeder cells, we tested the feasibility of long-term culture and cryopreservation of the established cell lines.

\section{Methods}

\section{Fish}

Siberian sturgeons (A. baerii) were reared by a water recycling system in hatchery of Pukyong National University (Busan, Korea) at ambient temperature and fed an artificial feed (Millennium Plus; Woosung Feed Corp., Daejeon, Korea). Five 1-year-old fish were used in this study, and the average body length and weight were $39.6 \pm 3.3 \mathrm{~cm}$ and $192.3 \pm 54.8 \mathrm{~g}$, respectively. All procedures for animal management, euthanasia, and surgery were complied with the guidelines of Institutional Animal Care and Use Committee (IACUC) of Pukyong National University and the ethical guidelines published by International Council for Laboratory Animal Science (ICLAS).

\section{Cell isolation and culture}

Gonad tissues were dissected from the body with sterile scissors and tweezers following disinfection with $70 \%$ ethanol (SK Chemicals, Sungnam, Korea). Each gonad was washed twice with Dulbecco's Phosphate-Buffered Saline (DPBS; Gibco, Grand Island, NY, USA) containing $1 \%(v / v)$ penicillin and streptomycin (P/S; Gibco) in petri dishes (SPL Life Sciences, Pocheon, Korea) and placed in a $35-\mathrm{mm}$ petri dish (SPL Life Science) filled with digestive solution consisting of a Leibovitz's L-15 Medium (L15; Gibco) supplemented with $500 \mathrm{U} / \mathrm{mL}$ collagenase type I (Worthington Biochemical Corporation, Lakewood Township, NJ, USA) and $0.05 \%$ trypsin EDTA (Gibco). Then, the tissues were chopped using a surgical blade and incubated for $30 \mathrm{~min}$ at $28{ }^{\circ} \mathrm{C}$. After digestion, enzyme was inactivated by adding $10 \%(v / v)$ fetal bovine serum (FBS; Gibco)-containing L15. All the tissue derivatives were filtered on $40-\mu \mathrm{m}$ cell strainers (BDFalcon $^{\mathrm{m}}$, San Jose, CA, USA), and the isolated cells were retrieved by centrifugation at $400 \times g$ for $4 \mathrm{~min}$. Viable cells were counted with a hemocytometer (Paul Marienfeld GmbH \& Co. KG, Lauda-Königshofen, Germany) after trypan blue (Gibco) staining, and $5 \times 10^{5}$ live cells were seeded in 24-well culture plates (SPL Life Sciences) with L15 containing $20 \%(v / v)$ FBS and $1 \%$ $(v / v) \mathrm{P} / \mathrm{S}$. The cells were cultured at $28{ }^{\circ} \mathrm{C}$ with an air atmosphere, and the culture media were changed every 2 to 3 days. Subcultures were conducted when the cells reached 90 to $100 \%$ confluency. For subculture, the cells were washed twice using DPBS supplemented with $1 \%$ $(v / v) \mathrm{P} / \mathrm{S}$ and detached by $0.05 \%$ trypsin EDTA at room temperature for $5 \mathrm{~min}$. After trypsin inactivation by adding one volume of $10 \%(v / v)$ FBS-containing L15, the detached cell suspension was centrifuged at $400 \times g$ for $4 \mathrm{~min}$. Then, the harvested cells were resuspended with culture media and subcultured at a 1:3 ratio up to the 7th passage and since then at a 1:5 ratio.

\section{Measurement of growth rate}

To investigate the growth rates under different culture conditions, $2.5 \times 10^{3}$ cells from each of three cell lines (designated as ABG1, ABG3, and ABG5) at passages 24 to 29 were seeded in 96-well microplates (Thermo Scientific, Vernon Hills, IL, USA) filled with L15 containing $20 \%(v / v)$ FBS and $1 \%(v / v) \mathrm{P} / \mathrm{S}$ and cultured under four different temperatures of $24,26,28$, and $30{ }^{\circ} \mathrm{C}$. Cell viability of each group was measured at days 1, 3, 5, and 7 after cell seeding using Cell Counting Kit-8 (CCK-8; Dojindo, Kushu, Japan) according to the manufacturer's instructions. After determination of optimal culture temperature, a test for determining optimal FBS concentration for cell growth was conducted under the optimal culture temperature. The same protocols with temperature test were used, but the cells were cultured in five different media consisting of L15 containing different FBS concentrations of $0,5,10,15$, and $20 \%$ under a fixed culture temperature. This experiment was conducted in triplicate.

\section{Analysis of DNA contents}

From each cell line, $1 \times 10^{7}$ cells at passages 54 to 55 were harvested by trypsinization and centrifugation. Cell pellets were suspended in $1 \mathrm{~mL}$ DPBS at room temperature and were transferred into $4 \mathrm{~mL}$ absolute ethanol at $-20{ }^{\circ} \mathrm{C}$. After overnight at $-20{ }^{\circ} \mathrm{C}$, the cells were harvested by centrifugation and rehydrated in $5 \mathrm{~mL}$ DPBS for $15 \mathrm{~min}$ at room temperature. After that, RNase A (Bioneer, Daejeon, Korea) was treated with a 
final concentration of $200 \mu \mathrm{g} / \mathrm{mL}$ in DPBS for $30 \mathrm{~min}$ at room temperature and, subsequently, stained by propidium iodide (Invitrogen, Carlsbad, CA, USA) with a final concentration of $10 \mu \mathrm{g} / \mathrm{mL}$ in the dark for $1 \mathrm{~h}$ at room temperature. Finally, DNA content was measured by an Accuri C6 flow cytometer (BD Biosciences, San Jose, CA, USA). A previously established $A$. baerii heart-derived cell line, the ploidy of which was confirmed (Kim et al., 2014), was used as a control of normal diploidy.

\section{RT-PCR}

Total RNA was extracted from each cell line using the RNeasy Plus Mini Kit (Qiagen, Valencia, CA, USA) at passages 15 to 16 and passages 54 to 55 . Extracted total RNA was treated by DNase I (Sigma-Aldrich, St. Louis, MO, USA) to eliminate genomic DNA, and first-strand complementary DNA (cDNA) was synthesized from $1 \mu \mathrm{g}$ total RNA using a M-MLV cDNA Synthesis Kit (Enzynomics, Daejeon, Korea). PCR was conducted with the primers specific for six genes including $a r, l h$, cyp17a1, sox9, star, and $\beta$-actin under the following condition: initial denaturation step $\left(94{ }^{\circ} \mathrm{C}\right.$ for $\left.5 \mathrm{~min}\right)$, cycling step $\left(30\right.$ cycles of $94{ }^{\circ} \mathrm{C}$ for $30 \mathrm{~s}, 60^{\circ} \mathrm{C}$ for $30 \mathrm{~s}$, and $72{ }^{\circ} \mathrm{C}$ for $45 \mathrm{~s})$, and the final extension step $\left(72{ }^{\circ} \mathrm{C}\right.$ for $\left.10 \mathrm{~min}\right)$. The PCR products mixed with LoadingSTAR (DyneBio, Seongnam, Korea) were size fractionated by $1.2 \%(w / v)$ agarose gel (Lonza, Rockland, ME, USA) electrophoresis and visualized with a UV transilluminator. The primer sequences are listed in Table 1.

\section{Measurement of viability of frozen-thawed cells}

To investigate cell viability after freezing and thawing, $2 \times 10^{5}$ cells from each cell line at passages 52 to 57 were suspended with freezing solution consisting of
L15 containing $10 \%(v / v)$ dimethyl sulfoxide (DMSO; Sigma-Aldrich) and $20 \%(v / v)$ FBS, and the cell suspensions were transferred into $1.2-\mathrm{mL}$ cryovials (Corning, Corning, NY, USA). Subsequently, the cryovials were frozen in pre-chilled freezing containers (Nalgene, Rochester, NY, USA) with the cooling rate of $-1{ }^{\circ} \mathrm{C} / \mathrm{min}$. After $12 \mathrm{~h}$ in a deep freezer at $-75^{\circ} \mathrm{C}$, the cryovials were stored in liquid nitrogen $\left(-196^{\circ} \mathrm{C}\right)$ for 24 to 27 days. The cells were thawed in a $37^{\circ} \mathrm{C}$ water bath for $2 \mathrm{~min}, 30 \mathrm{~s}$ and harvested by centrifugation. The post-thaw cells were suspended with culture media, and $1 \times 10^{4}$ cells were seeded in 96-well microplates. Cell viability was measured using CCK-8. Non-frozen cells were used as a control, and cell viability was calculated as absorbance sample $_{\text {a }}$ / absorbance $_{\text {control }} \times 100$. This experiment was conducted in triplicate.

\section{Statistical analysis}

The Statistical Analysis System (SAS Institute, Cary, NC, USA) program was used to analyze the effect of each treatment. When analysis of variance (ANOVA) detected a significant main effect, treatments were analyzed subsequently by Duncan's method. Significant differences among treatments were defined by a $p$ value $<0.05$.

\section{Results}

Establishment of $A$. baerii gonad-derived cell lines

Five gonad-dissociated cells derived from five individuals were subjected to in vitro culture. All cell populations were attached to substrata after 1 day of culture and reached 90 to $100 \%$ confluency in 4 to 6 days through continuous proliferation. They were subcultured continuously, and $1 \times 10^{6}$ cells of each were frozen at least once before the 10th passage. Each cell line was named

Table 1 Primer sequences used in this study

\begin{tabular}{|c|c|c|c|}
\hline Genes & Primer sequences $\left(5^{\prime}>3^{\prime}\right)$ & Product size (bp) & Accession number \\
\hline \multirow[t]{2}{*}{ ar } & Forward, TGAAGAAGATGAAGGGAGCAGAAGAT & 231 & DQ388357.1 \\
\hline & Reverse, TCTCCCCCAGTTCATTCAAGC & & \\
\hline \multirow[t]{2}{*}{ cyp17a1 } & Forward, TCACACACTCCAGTATTGGTG & 92 & HQ026486.1 \\
\hline & Reverse, CCATTCCTITTCATCGTGATG & & \\
\hline \multirow[t]{2}{*}{ Ih } & Forward, CTGCAGAGAAGGAGGAATGT & 140 & AJ251656.1 \\
\hline & Reverse, GCGAAGATCCTTATAGGTGCA & & \\
\hline \multirow[t]{2}{*}{ sox9 } & Forward, AGCAGCAAAAACAAGCCTCA & 113 & EU241882.1 \\
\hline & Reverse, AGCTCCGCGTTGTGAAGAT & & \\
\hline \multirow[t]{2}{*}{ star } & Forward, CAGAAGTCAATCAGCATCCT & 79 & FJ205610.1 \\
\hline & Reverse, TCAGCACCTTGTCTCCATTG & & \\
\hline \multirow[t]{2}{*}{$\beta$-actin } & Forward, CCCTGTTCCAGCCATCCTTC & 155 & JX027376.1 \\
\hline & Reverse, GTCTGCAATGCCAGGGTACA & & \\
\hline
\end{tabular}

Primer sequences for ar, cyp17a1, Ih, sox9, and star genes were referred from Berbejillo et al. (2012) ar androgen receptor, cyp17a1 cytochrome P450, family 17, subfamily a, polypeptide 1, Ih luteinizing hormone, sox9 sry-box containing gene 9 , star steroidogenic acute regulatory protein 
as ABG1, ABG3, ABG5, ABG6, and ABG7 (Table 2). Up to date, all the five cell lines have been cultured stably and constantly over at least the 73th passage and 402 culture days. For preservation and future use, all cell lines were cryopreserved in liquid nitrogen with a sufficient number of vials containing each cell lines at an interval of about 5 passages (Table 2).

\section{Determination of optimal growth condition}

To decide optimal growth conditions for A. baerii gonad-derived cell lines, the effects of temperature and FBS concentration on cellular growth were evaluated. As shown in Fig. 1, similar effects of temperature on cellular growth were observed in the three cell lines tested. Significant high cell growth was detected at both 28 and $30{ }^{\circ} \mathrm{C}(p<0.05)$, and it was decreased as temperature goes down. In $24{ }^{\circ} \mathrm{C}$, the lowest cell growth was observed, but the cells kept attaching on the substrata, maintained normal morphology, and grew slowly. To test the effects of FBS concentration on cellular growth, culture temperature was fixed at $28{ }^{\circ} \mathrm{C}$ according to the result of temperature test. As expected, absence of FBS in the culture did not induce both cell growth and attachment in all the cell lines tested and growth rate was increased in a dose-dependent manner. The ABG3 and ABG5 lines grew better significantly in the media containing 15 and $20 \%$ FBS relative to the other media while the ABG1 line showed maximum growth in the media containing $20 \%$ FBS $(p<0.05)$.

\section{Characterization of $A$. baerii gonad-derived cell lines}

During the culture period, all the cell lines were composed of mainly two types of cells based on morphological criteria: wide-spread cells that occupy a wide surface area and small polygonal cells that grow densely. At an early passage (passage nos. 15 to 16), a ratio of wide-spread cells was relatively higher than that of small polygonal cells in all cell lines and a certain difference among cell lines was not observed visually. As the cell lines were subcultured consistently, a ratio of small polygonal cells was relatively increased and some differences among cell lines appeared at a late passage (passage nos. 54 to 55). The ABG1 and ABG5 lines have maintained a high ratio of wide-spread cells, whereas the ABG3 and ABG6 lines contained dominantly small polygonal cells. In the ABG7 line, two cell types were mixed at a similar ratio (Fig. 2a). To evaluate ploidy of the cell lines after long-term culture, DNA contents of each cell line at late passage were measured by flow cytometry. As shown in Fig. 2b, all the five cell lines showed diploid DNA contents similar to the control cell line despite long-term culture. Two peaks within diploid peak of the ABG7 line are seemed to be caused by the property of the ABG7 line in which two cell types existed at the same ratio. Next, RT-PCR analysis was conducted to identify the expression of a set of genes that are known to be expressed in A. baerii gonad tissue in the established cell lines at both early and late passages. As the results, the expression of $a r, l h$, and sox 9 genes was maintained at late passage, more or less, in all the cell lines, but the cyp17a1 gene was not expressed at all in both early and late passages of all the cell lines. In case of the star gene, overall expression was weak with no expression in the ABG1 line and its expression in the ABG5 line was lost at late passage (Fig. 2c).

\section{Post-thaw cell viability of $A$. baerii gonad-derived cell lines}

To evaluate the feasibility of cryopreservation of the established cell lines, the viabilities of post-thaw cells which were frozen and stored in liquid nitrogen $\left(-196{ }^{\circ} \mathrm{C}\right)$ for 24 to 27 days were measured in each cell line. High post-thaw cell viabilities of more than $79.6 \%$ were detected in four cell lines including ABG1, 3, 5, and 7 (92.9, 79.6, 86.4, and $90.0 \%$, respectively), but the ABG6 line showed significant low post-thaw cell viability of $57.6 \%$ (Fig. 3; $p<0.05$ ).

\section{Discussion}

In this study, we successfully established five A. baerii gonad-derived cell lines from five trials (success rate, $5 / 5=100 \%)$ and all established cell lines could grow stably during a long period of more than 1 year without

Table 2 Information of Acipenser baerii gonad-derived cell lines established in this study

\begin{tabular}{|c|c|c|c|c|c|}
\hline \multirow{2}{*}{$\begin{array}{l}\text { Name of } \\
\text { cell line }\end{array}$} & \multicolumn{2}{|l|}{ Culture $^{a}$} & \multicolumn{3}{|l|}{ Cryopreservation $^{\mathrm{b}}$} \\
\hline & Passage no. in current & Culture period (day) & $\begin{array}{l}\text { First passage no. } \\
\text { cryopreserved }\end{array}$ & $\begin{array}{l}\text { Final passage no. } \\
\text { cryopreserved }\end{array}$ & $\begin{array}{l}\text { Total no. of frozen } \\
\text { vials stored }\end{array}$ \\
\hline$\overline{\mathrm{ABG} 1}$ & 80 & 504 & 9 & 80 & 46 \\
\hline$A B G 3$ & 73 & 434 & 7 & 73 & 58 \\
\hline ABG5 & 80 & 405 & 8 & 80 & 39 \\
\hline ABG6 & 78 & 525 & 5 & 70 & 54 \\
\hline ABG7 & 83 & 402 & 6 & 83 & 62 \\
\hline
\end{tabular}

${ }^{a}$ Composition of culture media was Leibovitz's L-15 medium supplemented with $20 \%(v / v)$ fetal bovine serum and $1 \%(v / v)$ penicillin and streptomycin

${ }^{\mathrm{b}} \mathrm{All}$ cell lines were frozen and stored in liquid nitrogen $\left(-196^{\circ} \mathrm{C}\right)$ 


\section{Temperature}
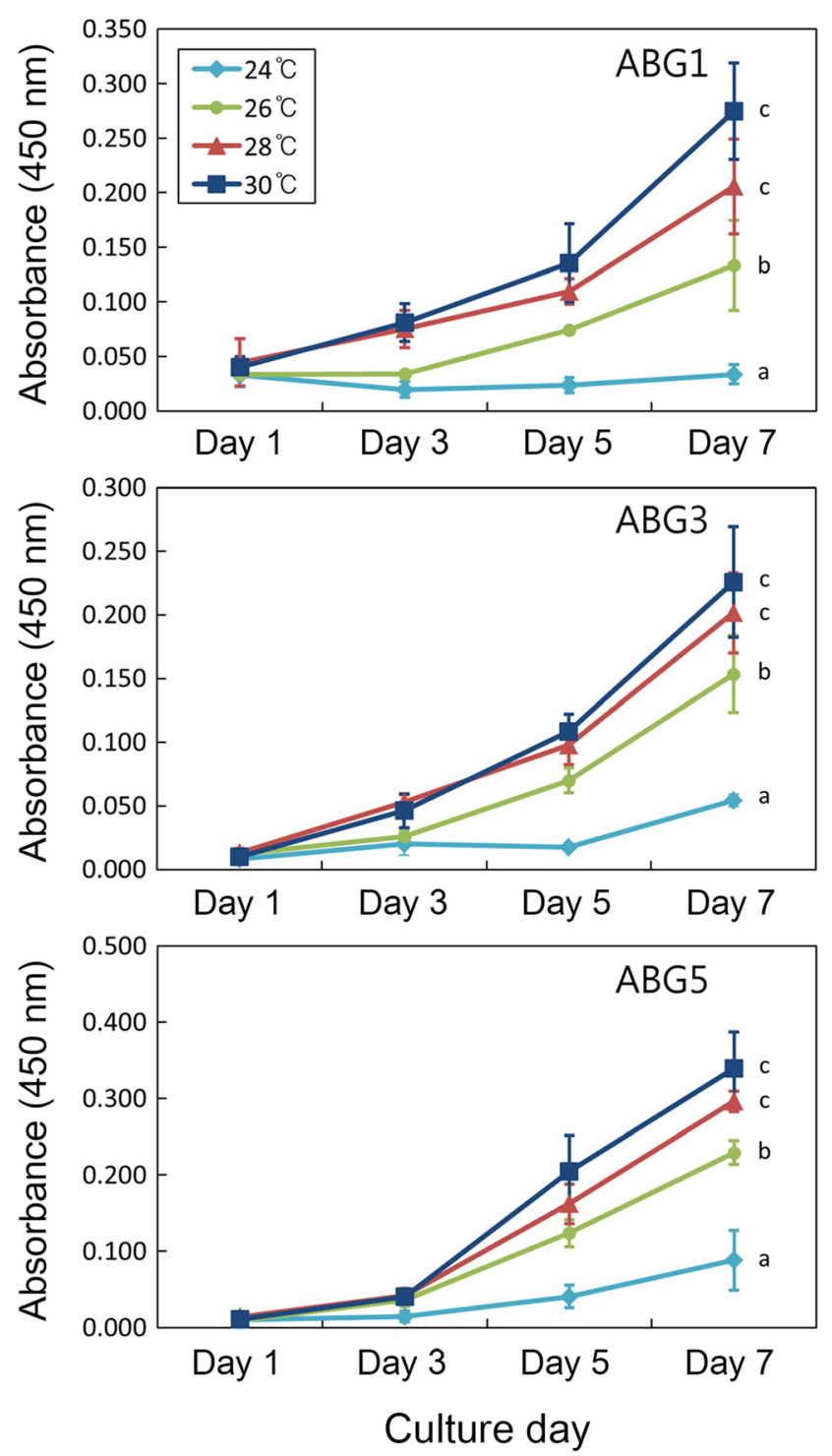

FBS concentration
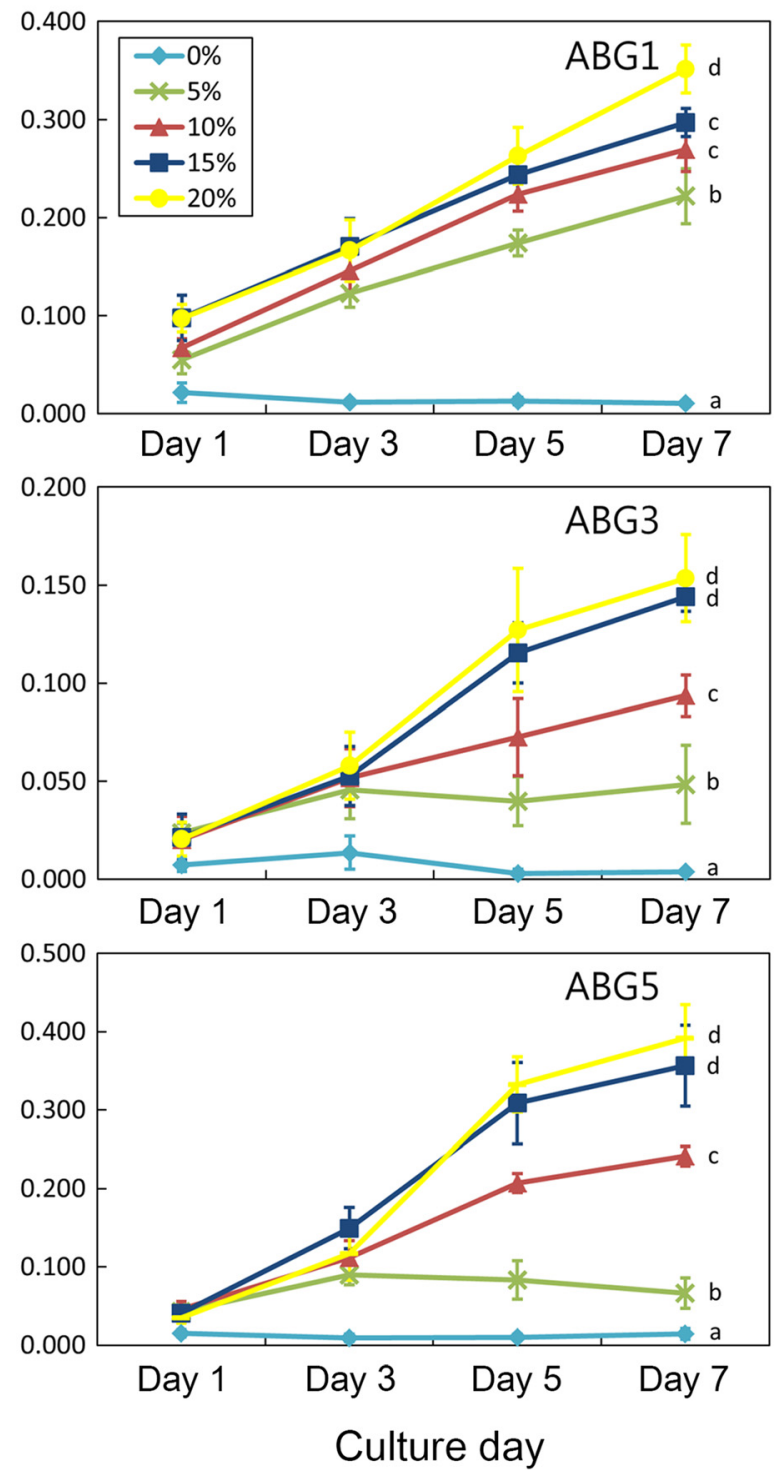

Fig. 1 Determination of optimal growth conditions for Acipenser baerii gonad-derived cell lines on temperature and fetal bovine serum (FBS) concentration. Three cell lines were cultured in 96-well microplates under different temperatures, and FBS concentrations and cell growth were measured on days $1,3,5$, and 7. FBS concentration was fixed at $20 \%$ in temperature test, and temperature was fixed at $28{ }^{\circ} \mathrm{C}$ in FBS concentration test. Significant high cell growth was observed in the cell groups cultured at 28 and $30{ }^{\circ} \mathrm{C}$ in all the three cell lines tested. In case of FBS concentration, 15 and $20 \%$ FBS induced significant high cell growth in the ABG3 and ABG5 lines, while the ABG1 line showed the maximum cell growth under $20 \%$ FBS. All data are mean \pm SD of three independent experiments. Different letters indicate significant differences, $p<0.05$

any significant growth retardation and marked deterioration in culture. Furthermore, these cell lines showed high post-thaw cell viabilities of more than $79.6 \%$ except one line that showed $57.6 \%$ post-thaw cell viability suggesting the feasibility of stable cryopreservation. These advantages of easiness in cell line derivation, long-term maintenance, and cryopreservation can maximize the availability of these cell lines as the feeder cells for culturing A. baerii germline stem cells. Culture of most stem cells requires continuous supply of feeder cells (Evans and Kaufman 1981; Matsui et al., 1992; Kanatsu-Shinohara et al., 2003; Takahashi and Yamanaka, 2006; Jing et al., 2010; Pacchiarotti et al., 2010). Thus, in case of the feeder cells that have a relatively short lifespan like mouse embryonic fibroblasts that are feeder cells for culturing human and mouse embryonic stem cells, sacrifice of animals and labor-intensive work for cell preparation should be conducted repeatedly (Amit et al., 2003). 


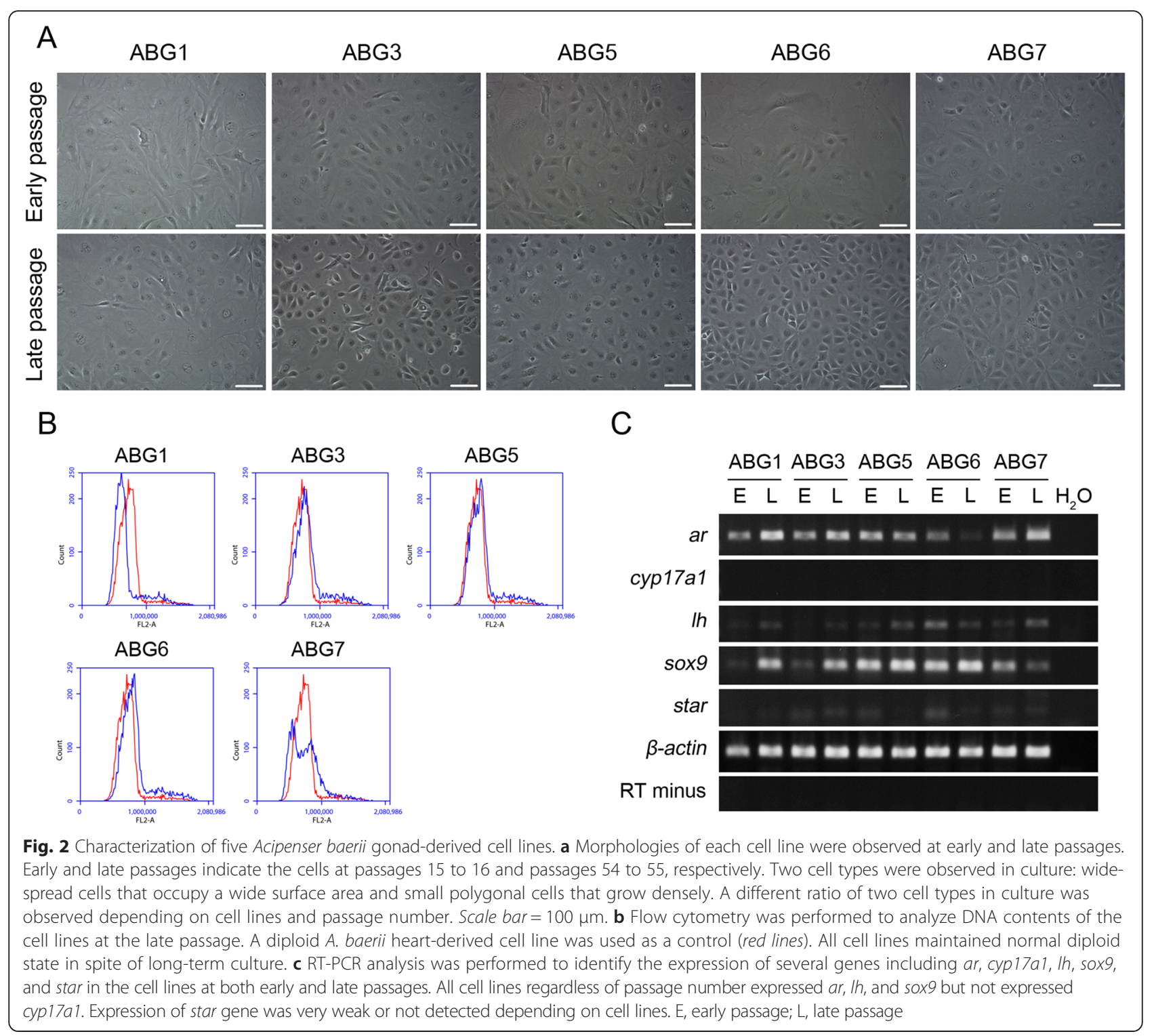

Unlike this, the cell lines that can grow long-term and be stored stably are free to such limitations. In addition, limitation of using A. baerii as an endangered species also can be overcome by the advantages. On the other side, these cell lines are able to play a role in universal biological studies such as toxicology and drug discovery, functional studies for genes and proteins, and study for cell-pathogen interaction (Lakra et al., 2011). Indeed, there is a report that conducted virus susceptibility test on Chinese sturgeon A. sinensis tail fin cell line to verify the feasibility of fish virus culture and isolation using a cultured cell line (Zhou et al., 2008).

For cell culture, we used $28{ }^{\circ} \mathrm{C}$ culture temperature and the media containing $20 \%$ FBS based on our previous report that cultured A. baerii heart-derived cell lines (Kim et al., 2014) and the results from the experiment in this study. However, other conditions also can be attractive based on our results. We found that the established cell lines could be cultured in a wide range of culture temperatures from 24 to $30{ }^{\circ} \mathrm{C}$ even though significant high cell growth was observed in 28 and $30^{\circ} \mathrm{C}$ conditions. Culture in various temperatures may have a potential merit as feeder cells because co-culture with germline stem cells may require a different optimal culture temperature as in the case of mammalian species (Lee et al., 2013). In addition, the results showed that $15 \%$ FBS also induced significant high cell growth at a similar level with $20 \%$ FBS in the ABG3 and ABG5 lines, suggesting that the application of a cell line-specific protocol can save overall cost by diminishing the use of high-cost FBS.

In general, tissue-derived primary cell populations in culture undergo a selection process by various factors 


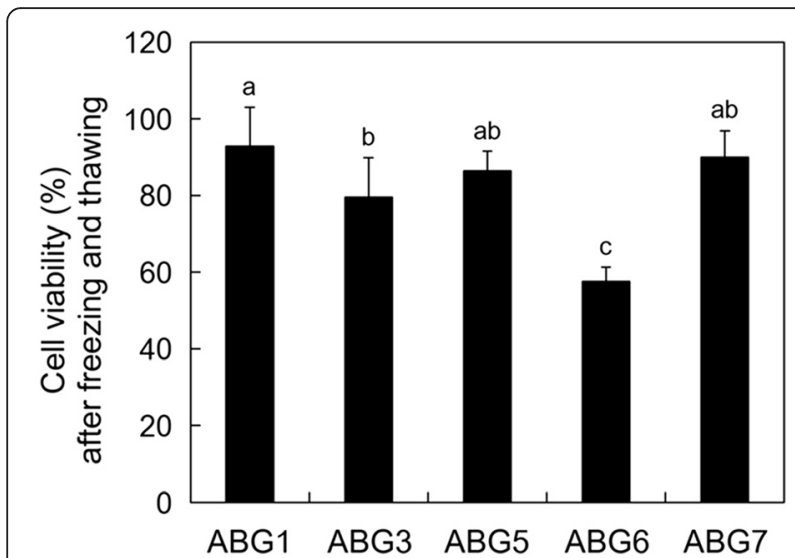

Fig. 3 Cell viability after freezing and thawing of five Acipenser baerii gonad-derived cell lines. Cell viability was measured immediately after thawing of frozen cells that were stored for 24 to 27 days in liquid nitrogen. More than $79.6 \%$ post-thaw cell viability was observed in all the cell lines except ABG6 that showed $57.6 \%$ cell viability. Non-frozen cells were used as a control. All data are mean \pm SD of three the independent experiments. Different letters indicate significant differences, $p<0.05$

such as cellular damage in isolation, cell attachment, limitations in nutrient or substrates, and growth competition between different cells. Thus, one or two cell types are eventually remained when a cell line forms in most case (Freshney, 2010). Likewise, we observed that two cell types were dominant in the culture of $A$. baerii gonad-dissociated cells in morphological criteria. At the initial stage of culture, it looked that wide-spread cells were more predominant than small polygonal cells but the proportion of one of the two cell types was increased as the culture was progressed in all the cell lines except the ABG7 line that showed a similar ratio of the two cell types. This indicates that both cell types can be easily adapted in the culture environment used in this study and they are the major targets for further study. In another aspect, two cell types may represent each cell population at different differentiation stages in a common cell lineage.

All cell lines showed diploid DNA contents at passages 54 to 55 , indicating that all cell lines maintained an original normal state without cell transformation featured by aneuploidy or heteroploidy (Freshney, 2010). Moreover, the genes expressed at early passage were still expressed at late passage in all except the star gene of the ABG5 line. Although the data is very limited in terms of the number of genes tested, this result implies that the cell lines maintained their original characteristics in some degree at least up to passages 54 to 55 . Taken together, these findings suggest that the A. baerii gonad-derived cell lines might be able to maintain their primary supportive role in germline stem cells in spite of long-term culture.
To establish gonad-derived cell lines, we used a 1year-old A. baerii of which sex cannot be indentified externally (Keyvanshokooh and Gharaei, 2010). Unfortunately, we could not carry out histological inspection of gonad tissues from which the cell lines were originated due to a lack of available sample. Moreover, because there is no marker to discriminate sex at a cellular level in this species, sex of the cell lines established in this study is not clear. Therefore, it remains to be demonstrated if which germline stem cells, female or male, the established cell lines can support better. In previous reports, in vitro culture of germline stem cells requires several growth factors such as fibroblast growth factor (FGF), glial cellderived neurotrophic factor (GDNF), leukemia inhibitory factor (LIF), or stem cell factor (SCF) (Matsui et al., 1992; Kubota et al., 2004; Zhang et al., 2011 in mammalian; Hong et al., 2004; Wong et al., 2013; Li et al., 2014 in fish). These growth factors can be supplied by feeder cells or exogenously. However, because commercially available growth factors are usually of human or mouse origin, supply of them by feeder cells seems to be more appropriate in fish germline stem cell culture (Wong et al., 2013). In this study, we did not identify the expression of the growth factors in the cell lines due to the absence of available information about them. Considering the importance of the growth factors in supporting germline stem cells in vitro, identification of their expression should be checked in future studies. Otherwise, the cell lines can be manipulated artificially so as to express stably such growth factors.

\section{Conclusions}

This study reports the establishment of five A. baerii gonad-derived cell lines that stable long-term culture and cryopreservation were possible. These cell lines can be utilized as a basic material to develop the culture system for germline stem cells in sturgeon species as well as a tool for general biological studies.

\section{Acknowledgements}

This work was supported by a Research Grant of Pukyong National University (year 2014).

\section{Authors' contributions}

JHR carried out the experiments and participated to write the manuscript. YKN conceived of the study and participated in its design. SPG conceived and designed the study, analyzed the data, and wrote the manuscript. All authors read and approved the final manuscript.

\section{Competing interests}

The authors declare that they have no competing interests.

\section{Author details}

${ }^{1}$ Department of Marine Biomaterials and Aquaculture, Pukyong National University, Busan 608-737, South Korea. ²Department of Fisheries Biology, Pukyong National University, Busan 608-737, South Korea. ${ }^{3}$ Laboratory of Cell Biotechnology, Department of Marine Biomaterials and Aquaculture, College of Fisheries Science, Pukyong National University, Busan 608-737, South Korea. 
Received: 27 January 2016 Accepted: 19 May 2016

Published online: 04 June 2016

\section{References}

Amit M, Margulets V, Segev H, Shariki C, Laevsky I, Coleman R, et al. Human feeder layers for human embryonic stem cells. Biol Reprod. 2003;68:2150-6.

Aponte PM, Soda T, Teerds KJ, Mizrak SC, van de Kant HJ, de Rooij DG. Propagation of bovine spermatogonial stem cells in vitro. Reproduction. 2008;136:543-57.

Berbejillo J, Martinez-Bengochea A, Bedo G, Brunet F, Volff JN, Vizziano-Cantonnet D. Expression and phylogeny of candidate genes for sex differentiation in a primitive fish species, the Siberian sturgeon, Acipenser baerii. Mol Reprod Dev. 2012;79:504-16

Brinster RL. Male germline stem cells: from mice to men. Science. 2007;316:404-5.

Evans MJ, Kaufman MH. Establishment in culture of pluripotential cells from mouse embryos. Nature. 1981;292:154-6.

Fan L, Moon J, Wong T,, Crodian J, Collodi P. Zebrafish primordial germ cell cultures derived from vasa::Rfp transgenic embryos. Stem Cells Dev. 2008;17:585-97.

Freshney RI. Culture of animal cells: a manual of basic technique and specialized applications. 6th ed. Hoboken: Wiley-Blackwell; 2010

Gisbert E, Ruban Gl. Ontogenetic behavior of Siberian sturgeon, Acipenser baerii: a synthesis between laboratory tests and field data. Environ Biol Fish. 2003; 67:311-9.

Guan K, Nayernia K, Maier LS, Wagner S, Dressel R, Lee JH, et al. Pluripotency of spermatogonial stem cells from adult mouse testis. Nature. 2006:440:1 199-203.

Hofmann MC, van Der Wee KS, Dargart JL, Dirami G, Dettin L, Dym M. Establishment and characterization of neonatal mouse Sertoli cell lines. J Androl. 2003;24:120-30

Hong Y, Liu T, Zhao H, Xu H, Wang W, Liu R, et al. Establishment of a normal medakafish spermatogonial cell line capable of sperm production in vitro. Proc Natl Acad Sci U S A. 2004;101:8011-6.

Hong N, Li Z, Hong Y. Fish stem cell cultures. Int J Biol Sci. 2011;7:392-402.

Jing D, Fonseca AV, Alakel N, Fierro FA, Muller K, Bornhauser M, et al. Hematopoietic stem cells in co-culture with mesenchymal stromal cells-modeling the niche compartments in vitro. Haematologica. 2010;95:542-50.

Kanatsu-Shinohara M, Ogonuki N, Inoue K, Miki H, Ogura A, Toyokuni S, et al. Long-term proliferation in culture and germline transmission of mouse male germline stem cells. Biol Reprod. 2003;69:612-6.

Kanatsu-Shinohara M, Inoue K, Takashima S, Takehashi M, Ogonuki N, Morimoto H, et al. Reconstitution of mouse spermatogonial stem cell niches in culture. Cell Stem Cell. 2012;11:567-78.

Kawasaki T, Saito K, Sakai C, Shinya M, Sakai N. Production of zebrafish offspring from cultured spermatogonial stem cells. Genes to Cells. 2012;17:316-25.

Keyvanshokooh S, Gharaei A. A review of sex determination and searches for sex-specific markers in sturgeon. Aquac Res. 2010;41:e1-7.

Kim MS, Nam YK, Park C, Kim HW, Ahn J, Lim JM, et al. Establishment condition and characterization of heart-derived cell culture in Siberian sturgeon (Acipenser baerii). In Vitro Cell Dev Biol Anim. 2014;50:909-17.

Kubota H, Avarbock MR, Brinster RL. Growth factors essential for self-renewal and expansion of mouse spermatogonial stem cells. Proc Natl Acad Sci U S A. 2004;101:16489-94

Lacerda SM, Costa GM, da Silva MA, Campos-Junior PH, Segatelli TM, Peixoto MT, et al. Phenotypic characterization and in vitro propagation and transplantation of the Nile tilapia (Oreochromis niloticus) spermatogonial stem cells. Gen Comp Endocrinol. 2013;192:95-106.

Lacerda SM, Costa GM, de França LR. Biology and identity of fish spermatogonial stem cell. Gen Comp Endocrinol. 2014;207:56-65.

Lakra WS, Swaminathan TR, Joy KP. Development, characterization, conservation and storage of fish cell lines: a review. Fish Physiol Biochem. 2011:37:1-20.

Lee WY, Park HJ, Lee R, Lee KH, Kim YH, Ryu BY, et al. Establishment and in vitro culture of porcine spermatogonial germ cells in low temperature culture conditions. Stem Cell Res. 2013;11:1234-49.

Lee $\mathrm{KH}$, Lee $\mathrm{R}$, Lee WY, Kim DH, Chung HJ, Kim JH, et al. Identification and in vitro derivation of spermatogonia in beagle testis. PLOS ONE. 2014;9: e109963.

Lehmann R. Germline stem cells: origin and destiny. Cell Stem Cell. 2012;10:729-39.

Li Z, Li M, Hong N, Yi M, Hong Y. Formation and cultivation of medaka primordia germ cells. Cell Tissue Res. 2014;357:71-81.
Loir M. Trout Sertoli cells and germ cells in primary culture: morphological and ultrastructural study. Gamete Res. 1989:24:151-69.

Matsui Y, Zsebo K, Hogan BL. Derivation of pluripotential embryonic stem cells from murine primordial germ cells in culture. Cell. 1992;70:841-7.

Nagano M, Ryu BY, Brinster CJ, Avarbock MR, Brinster RL. Maintenance of mouse male germ line stem cells in vitro. Biol Reprod. 2003:68:2207-14.

Pacchiarotti J, Maki C, Ramos T, Marh J, Howerton K, Wong J, et al. Differentiation potential of germ line stem cells derived from the postnatal mouse ovary. Differentiation. 2010:79:159-70.

Park TS, Kim MA, Lim JM, Han JY. Production of quail (Coturnix japonica) germline chimeras derived from in vitro-cultured gonadal primordial germ cells. Mol Reprod Dev. 2008;75:274-81.

Ruban G, Zhu B. Acipenser baerii, The IUCN Red List of Threatened Species 2010: e.T244A13046607. 2010.

Sakai N. Transmeiotic differentiation of zebrafish germ cells into functional sperm in culture. Development. 2002;129:3359-65.

Shikina S, Yoshizaki G. Improved in vitro culture conditions to enhance the survival, mitotic activity, and transplantability of rainbow trout type a spermatogonia. Biol Reprod. 2010;83:268-76.

Shikina S, Ihara S, Yoshizaki G. Culture conditions for maintaining the survival and mitotic activity of rainbow trout transplantable type A spermatogonia. Mol Reprod Dev. 2008:75:529-37.

Song Y, Duraisamy S, Ali J, Kizhakkayil J, Jacob VD, Mohammed MA, et al. Characteristics of long-term cultures of avian primordial germ cells and gonocytes. Biol Reprod. 2014;90:15.

Spradling A, Fuller MT, Braun RE, Yoshida S. Germline stem cells. Cold Spring Harb Perspect Biol. 2011;3:a002642.

Takahashi K, Yamanaka S. Induction of pluripotent stem cells from mouse embryonic and adult fibroblast cultures by defined factors. Cell. 2006;126:663-76.

Tiptanavattana N, Thongkittidilok C, Techakumphu M, Tharasanit T. Characterization and in vitro culture of putative spermatogonial stem cells derived from feline testicular tissue. J Reprod Dev. 2013;59:189-95.

Wong TT, Collodi P. Dorsomorphin promotes survival and germline competence of zebrafish spermatogonial stem cells in culture. PLOS ONE. 2013;8:e71332.

Wong TT, Tesfamichael A, Collodi P. Production of zebrafish offspring from cultured female germline stem cells. PLoS ONE. 2013;8:e62660.

Zhang Y, Yang Z, Yang Y, Wang S, Shi L, Xie W, et al. Production of transgenic mice by random recombination of targeted genes in female germline stem cells. J Mol Cell Biol. 2011:3:132-41.

Zhou GZ, Gui L, Li ZQ, Yuan XP, Zhang QY. Establishment of a Chinese sturgeon Acipenser sinensis tail-fin cell line and its susceptibility to frog iridovirus. J Fish Biol. 2008:73:2058-67.

\section{Submit your next manuscript to BioMed Central and we will help you at every step:}

- We accept pre-submission inquiries

- Our selector tool helps you to find the most relevant journal

- We provide round the clock customer support

- Convenient online submission

- Thorough peer review

- Inclusion in PubMed and all major indexing services

- Maximum visibility for your research

Submit your manuscript at www.biomedcentral.com/submit
) Biomed Central 